\title{
THE THYROID CYTOTOXIC AUTOANTIBODY
}

\author{
By I. J. FORBES,* I. M. ROITT, DEBORAH DONIACH AND I. L. SOLOMON $†$ \\ (From the Middlesex Hospital Medical School, London, England)
}

(Submitted for publication November 27, 1961 ; accepted January 18, 1962)

The presence of circulating autoantibodies in patients with Hashimoto's disease suggests that autoimmunity is implicated in the disease process, but the ultimate proof of an autoimmune pathogenesis of thyroiditis and other human diseases must be obtained by demonstrating the autoaggressive action of antibodies or immunologically competent cells on the living tissue in its normal environment.

The demonstration by Pulvertaft, Doniach, Roitt and Hudson $(1,2)$ of a serum factor capable of destroying human thyroid cells in tissue culture is an advance in this direction. This finding has been confirmed and amplified by Irvine $(3,4)$ and by Goudie and McCallum (5). Further investigations of this phenomenon are reported in the present paper. The cytotoxic factor is shown to be an antibody reacting with the thyroid microsomal antigen; its mode of action has been further studied and its incidence determined in a variety of thyroid conditions and in persons without overt thyroid disease.

\section{METHODS AND MATERIALS}

Tissue culture. Primary monolayer cultures of trypsindispersed thyroid epithelium were set up in chambers prepared on microscope slides by the method of Pulvertaft and co-workers (1). The chambers consisted of a plastic ring attached to a histology slide with silicone grease, and sealed with a coverslip. Fresh thyroid tissue was dispersed for 1 hour in 0.25 per cent trypsin (Difco, 1:250), and after centrifugation a suitable inoculum was prepared by adding a concentrated suspension of cells to Parker 199 medium until a density of 5 epithelial clumps per field was seen when a drop was viewed through a $10 \times$ objective. The ideal cell concentration resulted in the growth of 30 to 50 cell clumps in a control chamber. Each chamber contained $0.1 \mathrm{ml}$ of test serum, $0.1 \mathrm{ml}$ fresh normal serum, and $0.6 \mathrm{ml}$ of cell inoculum. The fresh normal serum used routinely had a complement titer of between 160 and 320 minimal hemolytic doses (MHD) per $\mathrm{ml}$, as determined by the

* Present address: University of Michigan Medical Center, Ann Arbor, Mich.

$\dagger$ Present address: Children's Hospital, Columbus, Ohio. micromethod of Donnelley (6), and was known to support good cell growth. Fresh normal serum was always used in tests with serum fractions or absorbed sera. Guinea pig serum could be used as a source of complement but was occasionally cytotoxic. The cultures were incubated for 18 to 24 hours at $37^{\circ} \mathrm{C}$.

The sensitivity of each gland was established by including as controls known weakly cytotoxic sera and potent Hashimoto sera, sometimes set up in dilutions. With sensitive glands, all the cells were killed by a strong standard serum; the weaker sera usually allowed a few clumps of cells to be established. Where cells survived in final dilutions of less than 1:120 of the standard strong serum, the gland was too insensitive to permit evaluation of unknown sera. Provided the gland was sensitive, a serum was judged to be cytotoxic when either no clumps of healthy cells were visible or there was a gross reduction of surviving cells relative to control cultures. All positive sera were retested in at least one subsequent culture.

Zone electrophoresis on "Pcvikon" blocks. This was carried out by a method similar to that of MüllerEberhard (7). Approximately $50 \mathrm{~g}$ of polyvinyl-chloride powder (Pevikon, Fosfatbolaget, Stockviksverkin, Sweden) washed three times in barbiturate buffer, $\mathrm{pH}$ 8.6, was made into a thick slurry and poured into a Perspex trough, $7 \times 2 \times 1 / 2$ inches. The serum was dialyzed overnight at $4^{\circ} \mathrm{C}$ against the buffer and a trace of bromophenol blue added. After equilibration of the block in the electrode chamber at $4^{\circ} \mathrm{C}$ for 30 minutes, 1.5 $\mathrm{ml}$ of serum was added to a depression in the block, 1 inch from the cathodal end. Electrophoresis was continued for approximately 18 hours in the cold, using a current of 7 ma until the blue-stained albumin was within 1 inch of the anodal end of the block. At the end of electrophoresis the block was cut transversely into six equal portions. The fractions were stirred with 2 $\mathrm{ml}$ of Parker's 199 medium in tubes and the supernatant recovered after centrifugation. Each fraction was dialyzed against $250 \mathrm{ml}$ of phosphate-buffered saline at $4^{\circ} \mathrm{C}$ (8) overnight, then against $10 \mathrm{ml}$ of Parker 199 for 8 hours. The fractions were stored at $-20^{\circ} \mathrm{C}$ until tested.

The protein fractions were identified by immunoelectrophoresis, with Scheidegger's (9) micromethod. Four drops of each fraction in serial fivefold dilutions were set up for tissue culture; $0.2 \mathrm{ml}$ of fresh normal human serum was added to each dilution. A duplicate undiluted tube from each fraction was inactivated at $56^{\circ} \mathrm{C}$ for 30 minutes before culture to ensure that cytotoxicity was complement dependent. 
Sodium sulfate precipitation of $\gamma$-globulins from cytotoxic sera. Two vol of 27 per cent sodium sulfate in phosphate buffer, $\mathrm{pH} 7.8$, was added to 1 vol of a cytotoxic serum, over a period of 10 minutes, with continuous stirring. After centrifugation at $10,000 \mathrm{rpm}$ for 10 minutes at room temperature, the supernatant was decanted and saved. The precipitate was washed in 18 per cent sodium sulfate and after centrifugation was dissolved in a volume of distilled water equal to the volume of the supernatant. The solutions were dialyzed against phosphate-buffered saline and Parker's 199 medium for use in the tissue culture test and for the detection of cytoplasmic antibodies by Coons' technique.

Chromatography of $\gamma$-globulin obtained by zone electrophoresis on Pevikon blocks. The first three fractions containing $\gamma$-globulin were used from two Pevikon blocks prepared according to the method described above. Chromatography was carried out on a diethylaminoethyl (DEAE)-cellulose column by the method of Fahey and Horbett (10).

The Pevikon fractions were eluted in Parker's 199 medium; the final volume of solution after elution was $9.5 \mathrm{ml}$. This solution was dialyzed against a $0.01 \mathrm{M}$ phosphate buffer, $\mathrm{pH} 8.1$, overnight.

The column was prepared with DEAE-cellulose from Serva Entwicklungslabor, Heidelberg, and washed through overnight with $0.01 \mathrm{M}$ phosphate buffer. The dialyzed $\gamma$-globulin solution was added to the column and washed on with $1 \mathrm{ml}$ of buffer. A further $48 \mathrm{ml}$ of buffer was passed through the column before gradient elution was begun. The gradient was developed by running a $0.10 \mathrm{M}$ phosphate buffer, $\mathrm{pH}$ 8.1, containing 0.35 $\mathrm{M}$ sodium chloride into a constant volume mixing chamber (volume, $280 \mathrm{ml}$ ) containing the original buffer. The eluate was collected in 4-ml aliquots. The absorbance at $280 \mathrm{~m} \mu$ in a $0.5 \mathrm{~cm}$ cell was measured in a Hilger spectrophotometer. The solutions were pooled into 4 fractions containing $32,48,40$, and $130 \mathrm{ml}$, respectively. The fractions were concentrated approximately 20 -fold overnight by applying a vacuum outside the solutions contained in dialysis tubing. The four concentrated fractions were dialyzed against phosphate-buffered saline and then Parker's 199 medium. All operations were carried out at $4^{\circ} \mathrm{C}$. The fractions and a heat-inactivated control of each were tested for cytotoxicity in the tissue culture test.

Sucrose gradient ultracentrifugation. Five-tenths $\mathrm{ml}$ of a 1:5 dilution of serum was layered above $4.5 \mathrm{ml}$ of a 12 to 36 per cent sucrose density gradient and the tubes spun at $35,000 \mathrm{rpm}$ in the SW 39 head of the Spinco model L ultracentrifuge for 15 hours. After centrifugation the bottom of the tube was pierced, and separate 19S and 7S fractions were collected. The proteins were identified by immunoelectrophoresis and tested for cytoplasmic antibody by Coons' technique. Dialyzed fractions were tested for cytotoxicity in one experiment.

Other tests for thyroid antibodies. Coons' fluorescent antibody technique was used for the determination of cytoplasmic staining of unfixed frozen sections of toxic thyroid gland, as described by Holborow, Brown, Roitt and Doniach (11). Antibodies to the colloid were demonstrated by alcohol-fixed thyroid sections (12). The tanned cell hemagglutination (TRC) test for thyroglobulin antibodies was carried out with a formalinized sheep cell preparation (13). The complement fixation test (CFT) was done with thyrotoxic gland homogenate using 2 MHD (14) or 11/4 MHD of complement.

Enzymes. The following were used for cell dispersal: trypsin (1:250 Difco Lab., Detroit, Mich.); collagenase (Worthington Biochemicals Corp., Freehold, N. J.) ; papain (British Drug Houses, Poole, England) ; and ficin (crude, Light \& Co., Colnbrook, England).

Case material. Patients with primary myxedema and thyrotoxicosis were accepted if the clinical evidence was unequivocal or was confirmed by laboratory studies. Cases of nontoxic nodular goiter may have included some in which focal thyroiditis was present but was not disclosed by laboratory studies. The patients with Hashimoto's disease were accepted on the criteria of myxedema with a firm smooth goiter which became smaller on thyroid therapy, or in euthyroid patients with diffuse goiter who had confirmatory evidence from $\mathrm{I}^{131}$ studies and serum protein abnormalities. The diagnosis of Hashimoto's disease was proved histologically in 29 of the 48 cases tested; of the remainder, 18 gave a positive precipitin test. This series was separate from that reported by Pulvertaft and colleagues (2). Sera were obtained from 118 relatives ( 72 siblings, 30 offspring, and 16 parents) of 54 propositi with thyroid disease, 46 with Hashimoto's disease, 2 with biopsy-proved focal thyroiditis, 4 with thyrotoxicosis, and 2 with suspected Hashimoto's disease.

Ninety-one control sera from persons without overt thyroid disease were obtained from the antenatal clinic (21 sera) and from the routine pathology laboratory. Diagnoses were obtained from information in the case notes. Sera of 27 blood donors, 8 healthy young adult medical workers, 4 relatives of an 11 year old girl with systemic lupus erythematosus, and 31 hospital patients were also tested. The diagnoses of the latter were: orthopedic conditions (6 cases), gingivitis, hepatic cirrhosis with aplastic anemia, dysmenorrhea, migraine, allergic rhinitis, ulcerative colitis, Addison's disease, parotitis, idiopathic thrombocytopenic purpura, anxiety states ( 3 cases), hypopituitarism, obesity ( 2 cases), lupus erythematosus ( 5 cases), diabetes mellitus, rheumatoid arthritis, ischemic heart disease, hypotension of unknown etiology, and idiopathic hemolytic anemia.

\section{RESULTS}

Requirements for complement. Heating cytotoxic serum to $56^{\circ} \mathrm{C}$ for 30 minutes abolished its cytotoxic effect, and addition of fresh normal human or guinea pig serum to the heated serum restored its potency. The addition of increasing amounts of fresh human serum to a heated cyto- 
TABLE I

Zone electrophoresis of cytotoxic serum*

\begin{tabular}{|c|c|c|c|c|c|c|c|}
\hline \multirow[b]{2}{*}{ Fraction } & \multirow{2}{*}{ Analysis } & \multicolumn{5}{|c|}{$\begin{array}{l}\text { Cytotoxic factor } \\
\text { Final dilutions }\end{array}$} & \multirow{2}{*}{$\begin{array}{c}\text { Titer of } \\
\text { cytoplasmic } \\
\text { staining }\end{array}$} \\
\hline & & 6 & 24 & 120 & 600 & 3,000 & \\
\hline $\begin{array}{l}1 \\
2 \\
3 \\
4 \\
5 \\
6\end{array}$ & $\begin{array}{r}\gamma \text {-Globulin } \\
\gamma \text {-Globulin } \\
\gamma+\beta_{2} \text { A-Globulin } \\
\alpha_{2}+\beta-\text {-Globulins } \\
\alpha_{1}+\alpha_{2} \text {-Globulins } \\
\alpha_{1} \text {-Globulin }+ \\
\text { albumin }\end{array}$ & $\begin{array}{l}+ \\
+ \\
+ \\
\pm \\
-\end{array}$ & $\begin{array}{l}+ \\
+ \\
\pm \\
- \\
-\end{array}$ & $\begin{array}{l} \pm \\
\pm \\
\pm \\
- \\
- \\
-\end{array}$ & $\begin{array}{l}- \\
\pm \\
- \\
- \\
-\end{array}$ & $\begin{array}{l}- \\
- \\
- \\
-\end{array}$ & $\begin{array}{c}10 \\
50 \\
10 \\
1 \\
\text { Neg. } \\
\text { Neg. }\end{array}$ \\
\hline
\end{tabular}

* All cells in culture killed, + ; few cells surviving, \pm ; good growth of cells, - .

$\dagger$ Titer given as reciprocal of highest dilution of fraction giving positive staining in relation to control section treated with negative serum.

toxic serum in the standard system showed that approximately $5 \mathrm{MHD}$ of complement were required to restore potency; thus $0.1 \mathrm{ml}$ of fresh serum was routinely used to provide an adequate excess.

Serum fractionation studies. The cytotoxic factor was completely precipitated by 18 per cent sodium sulfate in one experiment, while cytoplas- mic staining was simultaneously removed. Traces of activity remained in the supernatant in a further precipitation experiment.

In electrophoretic separations the cytotoxic factor was predominantly localized to the $\gamma$-globulin fractions of serum. The results of a typical separation are shown in Table I. The slow $\beta$-globulin fraction always had low cytotoxic activity, al-

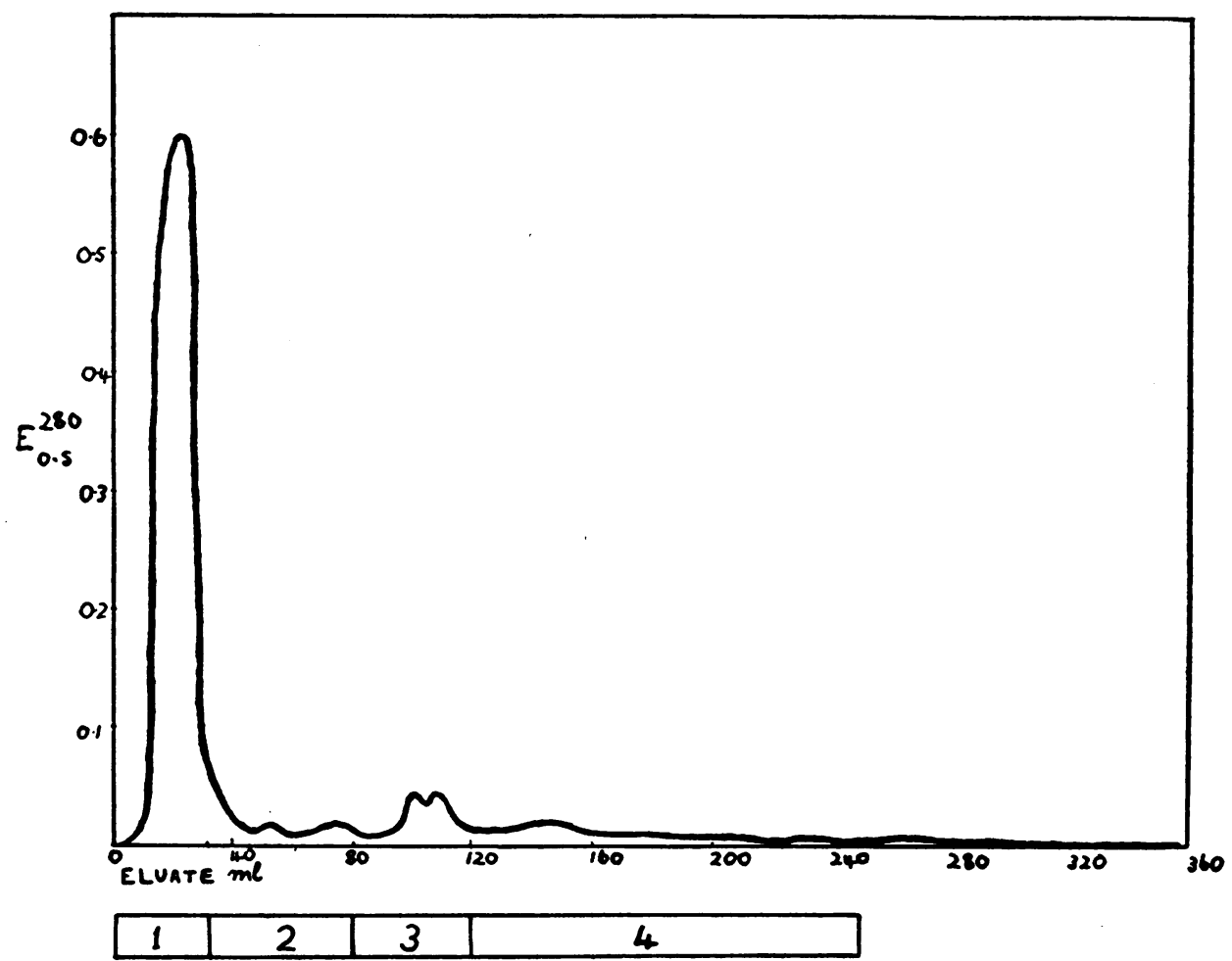

Fig. 1. Chromatography on DEAE-cellulose columns of $\boldsymbol{\gamma}$-globulin from cytotoxic SERUM OBTAINed BY zONE electrophoresis on "Pevikon" blocks. Pools of eluate used in testing for cytotoxic factor in tissue culture : $1,2,3,4$. 
TABLE II

Cytotoxicity of $\gamma$-globulin fractions obtained by DEAE-cellulose column chromatography

\begin{tabular}{cccccc}
\hline & \multicolumn{6}{c}{$\begin{array}{c}\text { Cytotoxic factor } \\
\text { Final dilutions }\end{array}$} \\
\cline { 2 - 6 } Fraction* & 6 & 24 & 120 & 600 & 3,000 \\
\hline 1 & + & + & \pm & \pm & - \\
2 & - & - & - & - & - \\
3 & - & - & - & - & - \\
4 & - & - & - & - & - \\
\hline
\end{tabular}

$* 1,2,3,4=$ fractions obtained by pooling eluate shown in Figure 1. See footnote $\left({ }^{*}\right)$ to Table I.

though $\gamma$-globulin could not always be identified in the eluate by immunoelectrophoresis. Parallel tests for cytoplasmic staining showed a correlation with cytotoxic activity (Table I). In four other experiments carried out with the same method the cytotoxic activity was found in the same fractions. In two of these experiments the complement-fixing and cytoplasmic antibodies were tested for and found to be contained in the $\gamma$-globulin fractions.

When $\gamma$-globulin fractions from two Pevikon blocks were chromatographed on DEAE-cellulose, (10), activity was recovered in the breakthrough peak containing 7S $\gamma$-globulin (Figure 1, Table II).

Five sera were fractionated by sucrose gradient centrifugation, and in each case cytoplasmic staining properties were recovered in the $7 \mathrm{~S}$ globulins, while no activity could be shown in the 19S fractions. In one experiment using dialyzed fractions in the tissue culture test, cytotoxicity was contained in the $7 \mathrm{~S}$ globulins.

Relationship of cytotoxic antibody to other thyroid autoantibodies. Although thyroglobulin and

TABLE III

Relationship of cytotoxic factor to thyroglobulin hemagglutinating antibody

\begin{tabular}{rccc}
\hline & & \multicolumn{2}{c}{ Cytotoxic factor } \\
\cline { 3 - 4 } Titer & Number & Present & Absent \\
\hline $2,500,000$ & 23 & 22 & 1 \\
250,000 & 9 & 9 & \\
25,000 & 13 & 12 & 1 \\
2,500 & 16 & 16 & 8 \\
250 & 19 & 11 & 5 \\
25 & 6 & 1 & 6 \\
5 & 6 & 48 & 124 \\
\hline
\end{tabular}

TABLE IV

Relationship of cytotoxic antibody to second colloid antibody

\begin{tabular}{cccc}
\hline \hline \multirow{2}{*}{$\begin{array}{c}\text { Second } \\
\text { colloid } \\
\text { antibody }\end{array}$} & Number & & \multicolumn{2}{c}{$\begin{array}{c}\text { Cytotoxic } \\
\text { antibody }\end{array}$} \\
\cline { 3 - 4 } & Present & Absent \\
\hline Present & 39 & 28 & 11 \\
Absent & 82 & 11 & 71 \\
\hline
\end{tabular}

cytotoxic antibodies commonly occur together, high-titer TRC or positive precipitins may be present in sera that do not contain the cytotoxic factor (Table III). This was found in two patients with Hashimoto's disease who had been treated with thyroxine. On the other hand, tests for thyroglobulin antibody were negative in 48 sera showing cytotoxic activity. Absorption of cytotoxic sera with thyroglobulin did not affect their cytotoxic titer. Further, of 39 sera with antibodies to the second colloid antigen, 28 had cytotoxic activity. Conversely, of 82 sera without colloid staining, 11 were cytotoxic (Table IV).

A close relationship was found between cytotoxicity and the presence of microsomal $\mathrm{CF}$ antibody (Table V) : of 86 sera giving thyroid-specific complement fixation, all were cytotoxic except one serum with a CFT titer of $1 / 4$. One other serum, from a patient with nontoxic nodular goiter having a CFT of $1 / 16$, was not cytotoxic. This serum also fixed complement with a saline extract of liver to a titer of 1/16. Cytoplasmic antibody was absent in both of these sera. Forty-five weakly cytotoxic sera gave negative results in the CFT when 2 MHD of complement were used for the test. However, when 13 of these sera were

TABLE V

Relationship of cytotoxic factor to microsomal complement-fixing antibody

\begin{tabular}{crrr}
\hline & & \multicolumn{2}{c}{ Cytotoxic factor } \\
\cline { 3 - 4 } CF titer & Number & Present & Absent \\
\hline 512 & 10 & 10 & \\
256 & 9 & 9 & \\
128 & 15 & 15 & \\
64 & 15 & 15 & \\
32 & 8 & 8 & \\
16 & 16 & 15 & 1 \\
8 & 8 & 8 & 1 \\
4 & 6 & 5 & 131 \\
Negative & 176 & 45 & 131 \\
\hline
\end{tabular}





Fig. 2. Left: Correlation of cytotoxicity of Hashimoto sera with complementFIXING ABILITY. The $\log _{10}$ of the reciprocal of the highest serum dilution showing cytotoxicity was plotted against $\log _{10}$ of the titer in the CFT test, with $11 / 4$ minimal hemolytic doses of complement.

Right: CoRrelation of CYtotoxicity of Hashimoto SERA with CYTOPlasmic stainING ABILITY. The $\log _{10}$ of the titer in the cytotoxic test was plotted against $\log _{10}$ of the reciprocal of the highest dilution giving positive fluorescent staining of thyroid cytoplasm in Coons' sandwich technique.

retested with $1 \frac{1 / 4}{4}$ MHD of complement and a higher antigen concentration, 9 were positive and 4 had become anticomplementary. In view of the difficulties inherent in determining the titer of cytotoxic activity, the correlation coefficient of 0.848 obtained between log (CFT titer) and $\log$ (cytotoxic titer) is good (Figure 2, left).

The fluorescent test appears to be the most sensitive and specific for microsomal antibodies, and results of cytoplasmic staining agreed well with cytotoxic tests $(\mathrm{r}=0.895$; Figure 2 , right; Table VI). Of 156 sera tested by both methods, 67 were positive in both, 83 were negative by the two tests, while weak cytoplasmic staining was obtained in 6 sera in which cytotoxicity could not be demonstrated. This apparent greater sensitivity of the fluorescent antibody test is undoubtedly due to the fact that undiluted serum is used,

TABLE VI

Relationship of cytotoxic factor to cytoplasmic antibody

\begin{tabular}{cccc}
\hline & & \multicolumn{2}{c}{$\begin{array}{c}\text { Cytotoxic } \\
\text { factor }\end{array}$} \\
\cline { 3 - 4 } $\begin{array}{c}\text { Cytoplasmic } \\
\text { antibody }\end{array}$ & Number & Present & Absent \\
\hline $\begin{array}{c}\text { Present } \\
\text { Absent }\end{array}$ & 73 & 67 & 6 \\
& 83 & & 83 \\
\hline
\end{tabular}

whereas the minimal serum dilution used in the cytotoxic test is $1: 8$.

Sensitivity of various types of thyroid tissue. The results obtained with different types of thyroid gland are summarized in Table VII. A1though small proportions of colloid goiter and "normal" tissues were susceptible, they were not satisfactory for testing unknown sera, since cells were not uniformly affected, and a variable number survived in the presence of potent sera. In three cases normal tissues were from the healthy

TABLE VII

Sensitivity of various types of thyroid tissue to cytotoxic factor; analysis of 49 cultures

\begin{tabular}{lrrrr}
\hline \hline \multicolumn{1}{c}{ Type of thyroid tissue } & $\begin{array}{c}\text { No. of } \\
\text { glands } \\
\text { cultured }\end{array}$ & \multicolumn{3}{c}{ Sensitivity* } \\
\cline { 4 - 6 } & 25 & & + & ++ \\
\hline Graves' disease & 4 & 1 & 1 & 20 \\
Toxic nodular goiter & 11 & 7 & 4 & \\
Nontoxic nodular goiter & 2 & 2 & & \\
Papillary carcinoma & 2 & & & \\
Metastasis of papillary & 1 & 1 & & \\
$\quad$ carcinoma & 1 & & 1 & \\
Hashimoto's disease & 4 & 2 & 2 & \\
Normal thyroid tissue & 1 & 1 &
\end{tabular}

* Good growth of cells in potent cytotoxic sera, - ; cells affected by potent sera only, + ; cells killed by low levels of cytotoxic antibody, ++ . 
lobe of glands with single adenomata; two were insensitive and the other partially sensitive. Unequivocally normal thyroid tissue taken during surgical exploration of the neck yielded cells that were killed by the high-titer sera but not by weakly active sera. Glands having a high content of microsomal antigen measured by the technique of Roitt, Doniach and Couchman (15) yielded sensitive cells while, in general, insensitive glands had a low antigen content. One gland with substantial lymphoid infiltration yielded highly sensitive cells, although the antigen content per gram of wet tissue was in the low range. Attempts to increase the sensitivity of cells from nontoxic nodular goiters by incubation with thyrotrophin, iodide, iodine, carbimazole, and thyrotrophin plus iodide in high concentration were unsuccessful. In these experiments primary cultures were set up in the presence of potent cytotoxic sera with added complement in the usual concentrations, and the following concentrations of these substances were added: thyrotrophin (Armour), $1.25 \mathrm{U}$ per ml; potassium iodide, $6.25 \mathrm{mg}$ per $\mathrm{ml}$; carbimazole, $0.25 \mathrm{mg}$ per $\mathrm{ml}$; Lugol's solution to give iodine $33.3 \mu \mathrm{g}$ per $\mathrm{ml}$; Lugol's solution as above plus thyrotrophin, $1.25 \mathrm{U}$ per $\mathrm{ml}$. In each case there was no reduction in the number of surviving cells as compared with control chambers containing cytotoxic sera only.

Sensitivity of autologous thyroid cells to autoantibodies. Serum containing cytotoxic factor killed cell cultures obtained from the patient's own gland provided this was sensitive with known positive sera. Cytotoxicity was demonstrated to autologous cells in 12 experiments, and in 4 other experiments the patient's serum having no cytotoxic factor allowed good growth of autologous cells.

The use of enzymes for cell dispersal. The possibility that the enzymes used for dispersal might affect the sensitivity of thyroid cells was investigated; 0.25 per cent trypsin, 1 per cent papain, 0.5 per cent ficin, and 0.1 per cent collagenase in Parker 199 medium released cells readily. Phasecontrast microscopy showed that cells were rapidly damaged by papain unless harvested and washed within 20 minutes. They were not readily released when papain was diluted in phosphatebuffered saline; with ficin, cells survived well for 1 hour.
The sensitivity of cells released by each enzyme was compared with that of trypsin-dispersed cells. While the cells obtained by all the enzymes were sensitive to cytotoxic factor, a small percentage of collagenase-treated cells survived in chambers containing cytotoxic sera, indicating a reduced sensitivity of cells dispersed by this enzyme. The best results were obtained when collagenase was mixed with trypsin. Ficin-treated cells were compared with trypsinized cells in four experiments. Concordant results were obtained on three occasions, but in one experiment the ficin-treated cells were insensitive, although the trypsinized cells from the same gland were fully susceptible to the cytotoxic antibody.

Absorption studies. Activity was absorbed from a strongly cytotoxic serum (titer $1 / 3,000$ ) by mixing $0.3 \mathrm{ml}$ of a $1: 10$ dilution of the serum with $0.2 \mathrm{ml}$ of packed trypsinized cells from a thyrotoxic gland. Cytotoxicity was similarly absorbed out when $0.3 \mathrm{ml}$ of a serum having a cytotoxic titer of $1 / 600$ was allowed to react at room temperature for 3 hours with $2.7 \mathrm{ml}$ of a 20 per cent toxic thyroid gland homogenate, the supernatant obtained being tested after centrifugation at $105,000 \mathrm{G}$ for 40 minutes. Cytotoxic effects were also abolished in two of three Hashimoto sera when $0.2 \mathrm{ml}$ of serum was absorbed with microsomes derived from $10 \mathrm{~g}$ of thyrotoxic tissue. Mitochondrial fractions from the same homogenate did not absorb out the factor, nor did comparable treatment with cells or microsomal fractions from colloid goiters.

Fluorescent tests on thyroid cells in culture. Fluorescein-conjugated Hashimoto serum was left in contact with living susceptible monolayers at $37^{\circ} \mathrm{C}$ for 45 minutes. There was no observable change in the cells, and only a faint halo of fluorescence was seen when the culture was viewed by ultraviolet light. Addition of complement produced cytotoxic changes showing that conjugated serum was still active. When monolayers from toxic and nontoxic glands were washed briefly and allowed to dry, the cytoplasm was weakly stained by conjugated globulins from a Hashimoto serum, while no fluorescence was observed with a conjugated normal serum. When conjugated antihuman- $\gamma$-globulin serum was applied after untreated Hashimoto serum (sandwich technique), the dried cells showed bright fluorescence. 
Far weaker staining of the cell cytoplasm was seen with normal controls, although some nonspecific uptake of $\gamma$-globulin occurred.

Cultures grown in normal serum were tested daily for susceptibility to cytotoxic factor, and the cytoplasmic staining of dried monolayers was compared (Table VIII). Cytotoxic serum and complement were applied to living cells and incubated for 30 minutes. Characteristic cytolytic changes were seen in 24-hour old monolayers-i.e., condensation and vesiculation of mitochondria, increased density of the nuclear membrane, loss of nuclear structure with final swelling, and rupture of the cells. A few cells remained sensitive in 48hour old monolayers, but no effects were obtained in older cultures.

\section{TABLE VIII}

Comparison of sensitivity of thyrotoxic cells in culture with cytoplasmic staining of dried monolayers at 24-hour intervals *

\begin{tabular}{|c|c|c|c|c|}
\hline & \multicolumn{4}{|c|}{ Age of culture (hours) } \\
\hline & 24 & 48 & 72 & 96 \\
\hline Sensitivity & + & \pm & - & - \\
\hline $\begin{array}{l}\text { Direct Hashimoto } \\
\text { conjugate }\end{array}$ & + & \pm & \pm & \pm \\
\hline $\begin{array}{l}\text { Direct normal } \\
\text { conjugate }\end{array}$ & - & - & - & - \\
\hline $\begin{array}{c}\text { Sandwich technique, } \\
\text { Hashimoto serum }\end{array}$ & ++ & ++ & + & + \\
\hline $\begin{array}{l}\text { Sandwich technique, } \\
\text { normal serum }\end{array}$ & \pm & \pm & + & $\begin{array}{l}\text { not } \\
\text { done }\end{array}$ \\
\hline $\begin{array}{l}\text { Rabbit antiglobulin } \\
\text { conjugate }\end{array}$ & \pm & \pm & \pm & \pm \\
\hline
\end{tabular}

* Strong cytoplasmic fluorescence, ++ ; weak cytoplasmic fluorescence, +; barely perceptible fluorescence, \pm ; no cyctoplasmic fluorescence, - .

Fluorescent staining was more specific with direct Hashimoto conjugates, and fluorescence was maximal at 24 hours, decreasing thereafter. The sandwich technique gave bright staining up to 48 hours and then decreased, but some staining was also seen with normal serum in controls.

Clinical incidence of cytotoxic factor. The incidence in various conditions is presented in Table IX. Cytotoxic factor was demonstrable in all but 2 of 48 Hashimoto subjects. A high incidence was also found in patients with focal thyroiditis, myxedema, and thyrotoxicosis. Weaker cytotoxic activity was demonstrable in a small proportion of patients with colloid goiters and thyroid carcinoma. Only 1 of 8 patients with histologically
TABLE IX

\begin{tabular}{|c|c|c|c|}
\hline \multirow[t]{2}{*}{ Condition } & \multirow[t]{2}{*}{$\begin{array}{c}\text { No. of } \\
\text { sera } \\
\text { tested }\end{array}$} & \multicolumn{2}{|c|}{$\begin{array}{c}\text { Cytotoxic } \\
\text { factor } \\
\text { present }\end{array}$} \\
\hline & & & $\%$ \\
\hline Hashimoto's disease & 48 & 46 & 96 \\
\hline Focal thyroiditis & 6 & 6 & \\
\hline Myxedema & 9 & 6 & \\
\hline Thyrotoxicosis & 51 & 34 & 67 \\
\hline Nontoxic nodular goiter & 31 & 5 & 16 \\
\hline Carcinoma of thyroid & 11 & 2 & \\
\hline Subacute thyroiditis & 8 & $\overline{1}$ & \\
\hline Mothers of cretins & 15 & 1 & \\
\hline \multicolumn{4}{|l|}{ Relatives of persons } \\
\hline having thyroid disease & 118 & 34 & 29 \\
\hline \multicolumn{4}{|l|}{ Lupus erythematosus } \\
\hline without thyroid disease & 4 & 0 & \\
\hline \multicolumn{4}{|l|}{ Lupus erythematosus } \\
\hline $\begin{array}{l}\text { with thyroid disease } \\
\text { Control series }\end{array}$ & $\begin{array}{r}3 \\
01\end{array}$ & 2 & \\
\hline Control series & 91 & 8 & 9 \\
\hline
\end{tabular}

proven de Quervain's disease had cytotoxic factor. Very weak cytotoxic antibody was found in 1 of 15 mothers of athyreotic cretins and the cytoplasmic staining given by her serum was also weak.

Eight of 91 sera ( 9 per cent) tested from persons without overt thyroid disease had cytotoxic antibody. In 7 of these the antibodies were weak as judged by their inability to kill all cells in a primary culture. Stronger cytotoxic antibodies were found in a case of acute hemolytic anemia. This serum was titered on a moderately sensitive gland and was completely cytotoxic at $1 / 6$ but did not affect the cells significantly at $1 / 24$. Serum taken after the hemolytic process had remitted under steroid therapy was barely cytotoxic even to highly susceptible cells. Three of these positive controls were found in a group of 21 pregnant women, and they gave birth to healthy babies. The other positive controls were a 75 year old

TABLE $X$

Incidence of cytotoxic factor in relatives of 54 persons having thyroid disease

\begin{tabular}{|c|c|c|c|}
\hline & Number & $\begin{array}{l}\text { Cytotoxic } \\
\text { factor }\end{array}$ & $\begin{array}{l}\text { Any thyroid } \\
\text { antibody* }\end{array}$ \\
\hline $\begin{array}{l}\text { Siblings } \\
\text { Offspring } \\
\text { Parents } \\
\text { Total }\end{array}$ & $\begin{array}{r}72 \\
30 \\
16 \\
118\end{array}$ & $\begin{array}{rl} & \% \\
19 & 26 \\
4 & 13 \\
11 & 69 \\
34 & 29\end{array}$ & $\begin{array}{rl} & \% \\
34 & 47 \\
7 & 23 \\
12 & 75 \\
53 & 45\end{array}$ \\
\hline
\end{tabular}

* One or more tests positive for thyroid antibodies (antibodies to thyroglobulin, second colloid antigen, or cytotoxic factor). 
woman with cardiovascular disease, a woman with other thyroid antibodies whose child had systemic lupus erythematosus, and two healthy subjects. Seven of the 8 cytotoxic control sera were tested for cytoplasmic staining and all gave positive results.

Thirty-four of 118 (29 per cent) close relatives of 54 persons with thyroid disease had cytotoxic antibodies. The highest incidence was found in parents (69 per cent). Twelve of the parents tested were female (cytotoxic factor in 8) and 4 were male ( 3 cytotoxic). The incidence in siblings and offspring was 26 and 13 per cent, respectively (Table X).

Cytotoxic activity was present in the sera of only 2 of 7 subjects with systemic lupus erythematosus and these had associated Hashimoto's disease.

\section{DISCUSSION}

The antibody nature of the cytotoxic factor was suggested by previous work showing that complement was required for activity and that the effect was organ and species specific $(1,2)$. Further support for this view was obtained in the present studies by the results of serum fractionation experiments. The cytotoxic factor was found to be stable at $56^{\circ} \mathrm{C}$ for 30 minutes, disproving the original suggestion that the antibody was heat labile (1). The factor was precipitated together with the $\gamma$-globulins by salt fractionation. After zone electrophoresis, virtually all of the activity was recovered in the $\gamma$-globulins; the low cytotoxicity associated with the slow $\beta$-globulin fraction may have been due to traces of $\gamma$-globulin in concentrations insufficient for detection by immunoelectrophoresis. These findings are at variance with the work of Irvine (4) who failed to isolate the cytotoxic factor in the $\gamma$-globulin fraction by both paper electrophoresis and Cohn fractionation. On ultracentrifugation the factor was localized in the $7 \mathrm{~S}$ fraction. Thus the cytotoxic factor has the properties of a normal low-molecular weight immune antibody in its ability to kill the patients' own thyroid cells in culture. Close correlations were established between cytotoxic potency, CFT titers, and cytoplasmic staining in individual sera. The inherent difficulties of determining accurate end points in the cytotoxic and cytoplasmic staining techniques allowed for, it appears that the different tests reflect interactions of the same antigen-antibody system. Activity in the three tests is unaffected by prior absorption of the sera with thyroglobulin or second colloid antigen but is abolished by treatment with thyroid fractions known to have a high content of microsomal antigen, such as toxic thyroid gland homogenates or microsomal preparations derived from them. Irvine (4) and Goudie and McCallum (5) also found that cytotoxic activity was removed by extracts of toxic thyroid tissue.

The variable sensitivity of thyroid glands further accords with the view that the microsomal antigen is involved both in cytotoxic activity and in cytoplasmic staining with fluorescent antibody. Thus the most consistently sensitive cultures are derived from the glands of patients with Graves' disease, although even among thyrotoxic thyroids weakly sensitive glands were encountered. Cells from toxic nodular goiters were sensitive in three of four cases, and in two cases even to weakly cytotoxic sera. Approximately half the nontoxic nodular goiters and normal thyroid glands were unaffected by Hashimoto sera, and the remainder were only weakly sensitive. The degree of sensitivity of a gland roughly parallels its content of microsomal CF antigen, the majority of thyrotoxic glands having a far higher content than has normal tissue (16). The presence of an adequate level of microsomal antigen appears to be paramount in determining the sensitivity of the cells. Loss of susceptibility to the factor, which occurs in sensitive cultures after 24 to 36 hours, closely follows a marked decrease in the staining ability of these cells in the fluorescent antibody test. This suggests that the antigen gradually disappears from the cultured cells. Leakage into the medium seems unlikely in view of the firm binding of the antigen in particulate structures within the cell (17). The influence of thyroxine and of thyroid-stimulating hormone on the level of $\mathrm{CF}$ antigen in the monkey thyroid (unpublished results) suggests that it is related to hormonal activity; if the antigen is a hormone precursor, its continued metabolism might deplete the cell in the absence of a precursor pool in the tissue culture environment. Denaturation of the antigen at the cell surface could also account for loss of sensitivity, and there is some evidence that the cytotoxic antibody acts on cells whose surface 
has been slightly modified by enzyme action. Preliminary experiments, in which minute fragments of human thyroid were cultured by the Trowell raft technique in the presence of 50 per cent Hashimoto serum with added complement, failed to show any specific tissue damage on subsequent histological examination of the fragments. Thus enzyme treatment appears to be essential for the preparation of sensitive cells, suggesting that surface digestion uncovers the required antigenic determinants. It is of interest that, in occasional experiments, collagenase or ficin-treated cells were definitely less sensitive than were those derived from the same gland treated with trypsin.

Further evidence that the cell surface is the reacting site derives from the studies made with fluorescein-conjugated Hashimoto serum. Inability to penetrate the living cells prevented the serum from staining the cytoplasm in healthy cultures, but faint surface staining was observed. In view of the lack of penetration of antibodies into living cells, the ability of trypsinized cell suspensions to absorb out cytotoxic activity from Hashimoto serum also argues for combination occurring at the cell surface. Previous studies on immune cytolysis with other cell systems such as HeLa cells $(18,19)$, and immune hemolysis (20), have emphasized the importance of cell surface interactions with the antibody. Electron microscope studies using ferritin-labeled antibody to HeLa cells (21), have shown that antibody combination is restricted to the cell surface until after the addition of complement, when binding to the subcellular elements of the cytoplasm can be observed after rupture of the cell membrane. Thus our tissue culture studies indicate that the same mechanisms obtain in autoimmune cytolysis as in heterologous immune systems.

The alteration of the cell surface apparently required for the demonstration of the cytotoxic effect makes it seem unlikely that normal thyroid cells can react with cytotoxic antibodies in vivo. Passive infusion into a monkey (14) of Hashimoto serum containing high levels of cross-reacting $\mathrm{CF}$ antibodies indeed failed to produce thyroid injury. The fact that the cytotoxic antibodies have been demonstrated in two-thirds of thyrotoxic patients who have only a mild and nonprogressive focal thyroiditis also suggests that their presence does not imply progressive tissue destruction.
However, patients with focal thyroiditis have much lower titers of cytotoxic factor than have untreated Hashimoto subjects and it may be that high-titer antibodies act synergistically with sensitized lymphoid cells. The lymphocytes may injure the cell membrane sufficiently [possibly during emperipolesis-i.e., intracellular wandering $(1,2)$ ] to allow the cytotoxic factor to enter into the cytoplasm where it exerts its full effect. It is of interest that Robineaux (22) was able to show by phase-contrast cinemicrography that slight surface injury of white blood corpuscles is sufficient to enable the lupus erythematosus factor to combine with live leukocytes.

The non-organ specific complement-fixing antibodies reacting with thyroid homogenates and with liver or other human and animal organs (AICF) do not produce cytotoxic effects in cultured thyroid cells, as shown by the negative results obtained with systemic lupus erythematosus and other AICF-reacting sera.

Blizzard and colleagues (23) and Beierwaltes, Dodson and Wheeler (24) put forward the suggestion that congenital athyreotic cretinism may be due in some cases to placental transmission of cytotoxic antibodies which presumably kill the fetal thyroid during pregnancy. We therefore tested 15 mother and cretin-baby pairs by tissue culture. Only one of the mothers' sera was weakly cytotoxic. Since similar weak cytotoxicity was demonstrated in 9 per cent of blood donors and mixed hospital patients without overt thyroid disease, the finding in this mother is not significant. Further, three mothers giving birth to healthy infants had cytotoxic antibody during pregnancy. Thus the hypothesis of placental transfer of cytotoxic antibody as a cause of cretinism receives no support from the present studies [see also Parker and Beierwaltes (25)], although it is conceivable that sensitized lymphocytes may occasionally overcome the placental barrier and destroy the fetal thyroid.

\section{SUMMARY}

1. The factor in Hashimoto sera cytotoxic for human thyroid cells in tissue culture has been shown to be a low-molecular weight $\gamma$-globulin, further confirming its antibody nature.

2. The cytotoxic antibodies are identical with or very closely related to the antibodies that fix 
complement in the presence of toxic thyroid microsomes, and are demonstrable by Coons' indirect fluorescent antibody technique in unfixed frozen sections of toxic thyroid tissues.

3. Thyroid glands having a high content of microsomal antigen yielded cells sensitive to the cytotoxic antibody, while insensitive glands had a low antigen content.

4. The cytotoxic antibodies were active against autologous thyroid cells in culture.

5. The loss, with time, in sensitivity of cultures to the cytotoxic antibodies parallels the loss in ability of the cells to stain with specific "antimicrosomal" sera in the Coons' fluorescent antibody technique.

6. Cytotoxic antibodies were found in 29 per cent of close relatives of patients with thyroid disease. Serum from patients with systemic lupus erythematosus was not cytotoxic except in two instances of an associated thyroiditis.

7. No evidence was obtained to support the view that athyreotic cretinism results from transplacental transfer of these cytotoxic antibodies.

\section{ACKNOWLEDGMENTS}

We wish to thank Professor A. Kekwick and the Clinical Research Committee for facilities afforded in the Institute of Clinical Research and are grateful to Professor Sir Charles Dodds and Professor F. Dickens for their unfailing support. We are greatly indebted to Professor R. J. V. Pulvertaft for help and advice with tissue culture techniques, and to Mr. K. G. Couchman and Mr. C. Shapland for skilled assistance. The work is supported in part by a grant to the Middlesex Hospital Medical School from the British Empire Cancer Campaign. Some equipment was generously donated by the Mary Kinross Charity Fund. Thanks are due to the Vaughan Hudson Clinical Research Trust, the Wellcome Trust (I.J.F.), and the Children's Hospital, Columbus, Ohio (I.L.S.), for financial support.

\section{REFERENCES}

1. Pulvertaft, R. J. V., Doniach, D., Roitt, I. M., and Hudson, R. V. Cytotoxic effects of Hashimoto serum on human thyroid cells in tissue culture. Lancet 1959, 2, 214.

2. Pulvertaft, R. J. V., Doniach, D., and Roitt, I. M. The cytotoxic factor in Hashimoto's disease and its incidence in other thyroid diseases. Brit. J. exp. Path. 1961, 42, 496.

3. Irvine, W. J. An investigation of the pathogenesis of Hashimoto's disease by thyroid tissue culture. J. Endocr. 1960, 20, 83.
4. Irvine, W. J. The cytotoxic factor in thyroid disease. Scot. med. J. 1960, 5, 511.

5. Goudie, R. B., and McCallum, H. M. Loss of tissuespecific autoantigens in thyroid tumors. Lancet 1962, 1, 348.

6. Donnelley, M. Studies in experimental immunology of influenza. VII. An improved complement-fixation technique. Aust. J. exp. Biol. med. Sci. 1951, 29, 137.

7. Müller-Eberhard, H. J. A new supporting medium for preparative electrophoresis. Scand. J. clin. Lab. Invest. 1960, 12, 33.

8. Dulbecco, R., and Vogt, M. Plaque formation and isolation of pure lines with poliomyelitis viruses. J. exp. Med. 1954, 99, 167.

9. Scheidegger, J. J. Une micro-méthode de l'immunoélectrophorèse. Int. Arch. Allergy 1955, 7, 103.

10. Fahey, J. L., and Horbett, A. P. Human gamma globulin fractionation on anion exchange cellulose columns. J. biol. Chem. 1959, 234, 2645.

11. Holborow, E. J., Brown, P. C., Roitt, I. M., and Doniach, D. Cytoplasmic localization of "complement-fixing" auto-antigen in human thyroid epithelium. Brit. J. exp. Path. 1959, 40, 583.

12. Balfour, B. M., Doniach, D., Roitt, I. M., and Couchman, K. G. Fluorescent antibody studies in human thyroiditis: Auto-antibodies to an antigen of the thyroid colloid distinct from thyroglobulin. Brit. J. exp. Path. 1961, 42, 307.

13. Fulthorpe, A. J., Roitt, I. M., Doniach, D., and Couchman, K. G. J. clin. Path. In press.

14. Roitt, I. M., and Doniach, D. Human auto-immune thyroiditis: Serological studies. Lancet 1958, 2, 1027.

15. Roitt, I. M., Doniach, D., and Couchman, K. Studies on an intracellular thyroid auto-antigen in Mechanisms of Antibody Formation. New York, Academic Press, 1960, p. 70.

16. Belyavin, G., and Trotter, W. R. Investigations of thyroid antigens reacting with Hashimoto sera: Evidence for an antigen other than thyroglobulin. Lancet 1959, 1, 648.

17. Roitt, I. M., Doniach, D., Wilson, E. G., and Couchman, K. Biochemical studies of thyroid autoantigens. Bull. Soc. Chim. biol. (Paris) 1960, 42, 1165.

18. Goldberg, B., and Green, H. Immune cytolysis. I. The release of ribonucleoprotein particles. II. Membrane-bounded structures arising during cell fragmentation. J. biophys. biochem. Cytol. 1960, 7, 645.

19. Hiramoto, R., Goldstein, M. N., and Pressman, D. Limited fixation of antibody by viable cells. $\mathrm{J}$. nat. Cancer Inst. 1960, 24, 255.

20. Lepow, I. H., and Ross, A. Studies on immune cellular injury. II. Functional role of $\mathrm{C}^{\prime} 1$ esterase in immune cytotoxicity. J. exp. Med. 1960, 112, 1107. 
21. Easton, J., Goldberg, B., and Green, H. Electron microscopic localization of ferritin-labeled antibody in ascites tumor cells. Fed. Proc. 1961, 20, 16.

22. Robineaux, R. Study of L. E. cell formation by phase contrast microcinematography in Henry Ford Hospital International Symposium on Mechanisms of Hypersensitivity, J. H. Shaffer, G. A. LoGrippo, and M. W. Chase, Eds. Boston, Little, Brown, 1959 , p. 371.
23. Blizzard, R. M., Chandler, R. W., Landing, B. H., Pettit, M.D., and West, C. D. Maternal autoimmunization to thyroid as a probable cause of athyrotic cretinism. New Engl. J. Med. 1960, 263, 327.

24. Beierwaltes, W. H., Dodson, V. N., and Wheeler, A. H. Thyroid autoantibodies in the families of cretins. J. clin. Endocr. 1959, 19, 179.

25. Parker, R. H., and Beierwaltes, W. H. Thyroid antibodies during pregnancy and in the newborn. J. clin. Endocr. 1961, 21, 792. 